Gut, 1982, 23, 724-728

\title{
Demonstration of non-specific B-cell stimulation in patients with cirrhosis*
}

\author{
G HOLDSTOCK, W B ERSHLER, and E L KRAWITT $\dagger$ \\ From the Department of Medicine, University of Vermont, Burlington, Vermont, USA
}

SUMMARY Using a sensitive enzyme-linked immunosorbent assay technique to measure immunoglobulins produced by peripheral lymphocytes, patients with cirrhosis with, and without, hypergammaglobulinaemia were found to produce significantly more spontaneous IgG than controls $(\mathrm{p}<0.005)$. There was no difference in IgG production when pokeweed mitogen, a T-cell dependent B-cell mitogen, was added to the system. Contrary to our findings in a T-cell proliferative assay, there was no evidence of increased prostaglandin-producing suppressor cell activity in this system. To study the importance of B-cell stimulation in cirrhotic hyperglobulinaemia, normal mononuclear cells were exposed either to cirrhotic or to control sera before measuring spontaneous IgG production. Cells exposed to cirrhotic sera produced significantly more IgG than those exposed to the control sera $(\mathrm{p}<0.02)$. These findings suggest that non-specific B-cell activity occurs with patients in cirrhosis and it is argued that the severity of the hypergammaglobulinaemia in patients with cirrhosis is more likely to depend on the degree of non-specific B-cell stimulation than on the competence of the immunoregulatory system.

Hypergammaglobulinaemia is a recognised feature of chronic liver disease. ${ }^{1}$ This observation, together with the known increase in antibody titres to a number of gut-associated antigens, ${ }^{23}$ indicates a hyper-responsive humoral immune system in these patients. This is in sharp contrast with the welldocumented hyporesponsive cellular immune system associated with cirrhosis. ${ }^{4}$

Two basic theories have been put forward to explain the hypergammaglobulinaemia. ${ }^{5}$ Firstly, reduced suppressor cell activity may fail to 'switch off' the immunoglobulin production. Such disordered immunoregulation has been demonstrated in proliferative assays in chronic active hepatitis, ${ }^{6}$ and, more recently, in severe alcoholic liver disease. ${ }^{7}$ Secondly, it is suggested that the decreased filtering capacity of the liver in cirrhosis allows gut-related antigens to spill over into the systemic

* Presented in part at the annual meeting of the American Association for the Study of Liver Diseases, Chicago, IL. 8 November 1981 and published in abstract form, Hepatology 1981; 1: 517 .

+ Address for correspondence: Professor E L Krawitt, Gastroenterology Unit, Department of Medicine, University of Vermont, Burlington, VT 054405, USA.

Received for publication 31 December 1981 circulation resulting in non-specific B-cell stimulation.

The recent development of sensitive assays has allowed in vitro immunoglobulin production by mononuclear cells to be measured. Various workers have shown that peripheral blood mononuclear cells from patients with cirrhosis, with or without hypergammaglobulinaemia, produce more immunoglobulin in vitro than do cells from controls. ${ }^{8-11}$ Although there are many different clones of antibody-producing cells in the systemic lymphoid system, ${ }^{12}$ it has been suggested that this system provides a useful model for the in vitro study of cirrhotic hypergammaglobulinaemia.

In this study we compare the immunoglobulinproducing capacity of peripheral mononuclear cells from cirrhotics with that of cells from normal controls and investigate the possibility that cirrhotic serum contains factors capable of stimulating normal cells to produce increased amounts of immunoglobulin. We have also studied prostaglandin-producing suppressor cell activity in this system, as we have previously shown that increased activity of this system may account for the hyporesponsiveness of the cellular immune system in cirrhosis. ${ }^{13}$ 
Methods

\section{SUBJECTS}

Thirteen patients with cirrhosis confirmed by biopsy were studied (one, primary biliary cirrhosis, eight, chronic active hepatitis, two, cryptogenic, and two, alcoholic). Only two had hypergammaglobulinaemia. The age range was 15 to 74 years and there were nine females and four males. Thirty-one healthy laboratory and hospital staff served as a control population. Twelve were male and 19 female and their age range was 22 to 58 years. Both patients and controls gave informed consent and the study conformed to the guidelines of the Committee on Human Experimentation of the University of Vermont.

\section{PREPARATION OF PERIPHERAL BLOOD}

MONONUCLEAR CELLS

These cells were obtained by density centrifugation by layering fresh heparinised $(10 \mathrm{u} / \mathrm{ml})$ venous blood on Ficoll-Hypaque. Mononuclear cells were recovered and washed three times with phosphate buffered saline. Cell suspensions were made in RPMI-1640 with $25 \mathrm{mM}$ hepes (GIBCO) and supplemented with penicillin $(100 \mathrm{u} / \mathrm{ml})$, streptomycin $(100 \mu \mathrm{g} / \mathrm{ml})$, and $2 \mathrm{mM}$ glutamine (Microbiological Associates) (RPMI-PSG). Trypan blue exclusion was used to assess viability and any preparation less than $90 \%$ viable was discarded.

\section{CULTURE AND ASSAY FOR IMMUNOGLOBULIN}

DETERMINATION

Immunoglobulin synthesis in vitro was assayed as previously described..$^{14}$ Briefly, $10^{6}$ peripheral blood mononuclear cells were cultured in sterile $12 \times 75 \mathrm{~mm}$ test tubes (Falcon) in $2 \mathrm{ml}$ RPMI-PSG supplemented with $10 \%$ fetal calf serum. For each subject cultures were established with or without $50 \mu \mathrm{g}$ pokeweed mitogen (GIBCO), a T-dependent B-cell mitogen ${ }^{15}$ which stimulates immunoglobulin synthesis. The effects of indomethacin on the in vitro stimulated immunoglobulin production were studied as indicated below. Cultures were incubated at $37^{\circ} \mathrm{C}$ in a fully humidified atmosphere in $5 \% \mathrm{CO}_{2}$ for seven days. Upon completion of the culture period, the specimens were centrifuged and the supernatants removed and stored at $-20^{\circ} \mathrm{C}$ for later assay of immunoglobulins. The concentration of IgG in the supernatant of the lymphocyte cultures was measured by an enzyme-linked immunosorbent assay technique modified ${ }^{14}$ from that described by Engvall. ${ }^{16}$ For this, polystyrene microtitre plates (Dynatech, Alexandria, VA) were coated with anti-human IgG (Cappel Laboratories, Cochranville, PA). Samples of the supernatant, diluted in phosphate buffered saline supplemented with $0.05 \%$ v/v Tween-20 (PBS-T) (Sigma, St Louis) were incubated in triplicate overnight at $4^{\circ} \mathrm{C}$. After a brisk wash with PBS-T, alkaline-phosphatase conjugated goat anti-human IgG (Miles Yeda, Rehovet, Israel) was added and the plates incubated overnight at $4^{\circ} \mathrm{C}$. After an additional wash, pnitrophenylphosphate (Sigma, St Louis) was added and the product of the enzymatic cleavage of this compound measured spectrophotometrically at $405 \mathrm{~nm}$ (Dynatech, manual enzyme-linked immunosorbent assay plate reader). Serial dilutions of standard immunoglobulin preparations served as a standard on each plate, from which the sample IgG values were calculated.

\section{MITOGENS AND DRUGS}

The optimal concentration for pokeweed mitogen proved to be $50 \mu \mathrm{g}$ per culture. Concentration of indomethacin was $1 \mu \mathrm{g} / \mathrm{ml}$. The effect of indomethacin on immunoglobulin synthesis (\% suppression) was calculated from the formula:

$$
\left(1-\frac{A}{B}\right) \times 100
$$

in which $\mathbf{A}$ indicates immunoglobulin production without indomethacin added and $B$ that produced in the presence of indomethacin.

\section{PRESENTATION AND STATISTICAL ANALYSIS OF} DATA

The final values were the mean of triplicate assays. These values were usually within $10 \%$ of the mean. Values were expressed as mean \pm standard error. The unpaired Student's $t$ test was used for comparison of group data and the paired Student's $t$ test for analysis of indomethacin on lymphocyte response.

\section{EFFECT OF SERUM FACTORS}

To investigate the effect of cirrhotic serum on normal cells, a large number of cells were obtained from a single healthy volunteer and made up in aliquots into 40 diufferent specimens, 20 of which were exposed to serum from cirrhotic patients and 20 to serum from controls matched as far as possible for age and sex. These 20 patients consisted of the original 13 plus four patients with chronic active hepatitis, one with primary biliary cirrhosis, and two alcoholics, all of whom had cirrhosis confirmed by biopsy. Cells were incubated in a 50\% concentration of the respective serum for 24 hours at $37^{\circ} \mathrm{C}$ in a fully humidified atmosphere. They were then washed in phosphate buffered saline five times, re-counted, and set up in culture for immunoglobulin production as previously described. Assay of the final washing 
fluid showed that there was no immunoglobulin remaining in this wash. Check samples were tested for viability by trypan blue exclusion at all stages of culture and all were found to be at least $90 \%$ viable.

\section{Results}

In vitro IgG production by unstimulated peripheral blood mononuclear cells from the cirrhotics was significantly greater than that of the controls ( $p<0.005$, Fig. 1). There was no difference between the cirrhotics and the controls after stimulation with pokeweed mitogen. The amount of unstimulated IgG production did not correlate with the circulating globulin level ( $r 0.09)$ and did not appear to depend on the nature of the liver disease, although numbers were too small for detailed analysis. There was no significant difference between the changes produced by the addition of indomethacin in the two groups $(-38 \% \pm 24$ for the controls and $-32 \% \pm 29$ for the cirrhotics).

Normal cells exposed to cirrhotic serum produced significantly more IgG than those exposed to normal control serum $(p<0.02$, Fig. 2). Seven of the cirrhotic sera (four chronic active hepatitis, one primary biliary cirrhosis, one alcoholic) resulted in IgG production greater than 2 SD from the mean of

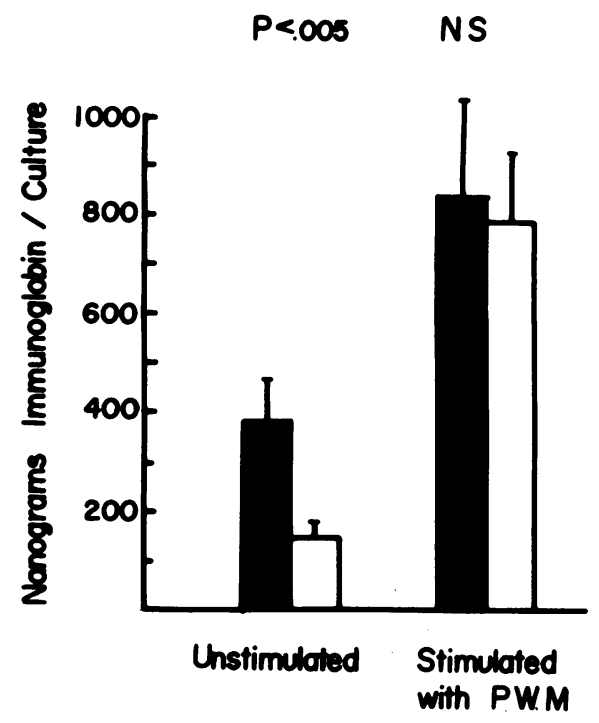

Fig. 1 IgG production by lymphocytes incubated for seven days in the absence or presence of pokeweed mitogen (PWM) from patients with cirrhosis ( $\square$ ) and by controls that produced by the cirrhotic serum. There was no correlation with the amount of IgG produced by the normal cells on exposure to the cirrhotic sera and the globulin levels in the specimens $(r 0 \cdot 1)$.

\section{Discussion}

These results confirm previous reports ${ }^{8-11}$ which have shown increased immunoglobulin production by mononuclear cells from patients with cirrhosis. Of greater interest is the finding that there are substances in cirrhotic serum that are capable of stimulating normal cells to produce increased amounts of immunoglobulin. The results provide evidence that non-specific B-cell stimulation does occur in cirrhosis and might account, at least in part, for the hypergammaglobulinaemia in these patients. This finding is in contrast with the effect of cirrhotic serum on the proliferative responses of both $T$ and $B$ cells on which cirrhotic serum has been shown to have marked inhibitory effects ${ }^{413}$ and suggests that immunoglobulin synthesis is not dependent on the proliferative response of the B cells. Other studies have shown that the number of circulating $B$ lymphocytes is not increased in patients with cirrhotic hypergammaglobulinaemia. ${ }^{17}$ The alternative interpretation that cirrhotic sera contain

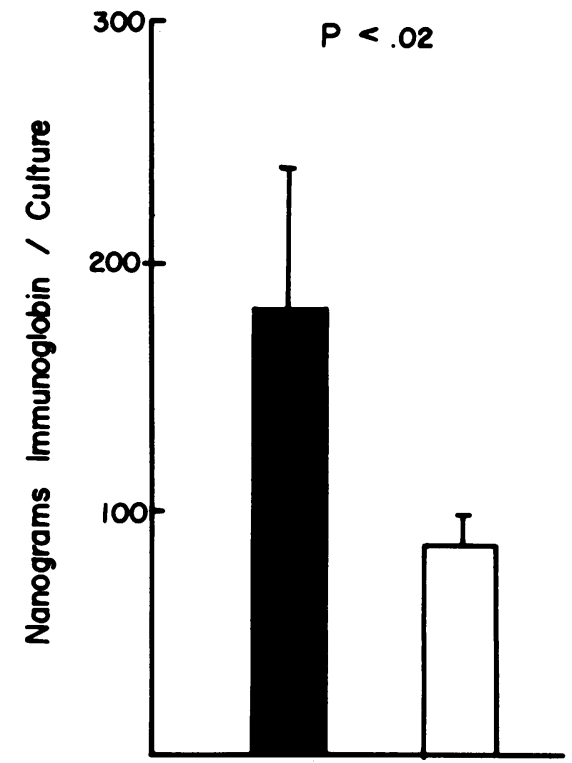

Fig. 2 Effect of serum from cirrhotics ( $\square$ ) and controls (D) on IgG production by normal cells which had been exposed to serum for 24 hours, washed, and then incubated for seven days in the absence of pokeweed mitogen. 
(or are lacking) a substance which preferentially affects the immunoregulatory cells of the normal donor cannot be excluded but appears unlikely. As endotoxin in vitro is known to stimulate B cells, it may be one of the antigens accounting for the increased spontaneous IgG production in the cirrhotics, as endotoxaemia may be common in patients with cirrhosis. 1819

In cirrhotic patients, the amount of immunoglobulin produced in response to adding pokeweed mitogen to the system was not statistically different from that of controls, and only the unstimulated levels differed. As pokeweed mitogen is a T-cell dependent B-cell mitogen ${ }^{15}$ this suggests that, in these patients, the regulatory system is intact and that defects of this system are of secondary importance. The non-specific B-cell stimulation that has been demonstrated may occur in all cirrhotics to some degree, as in clinical studies the degree of hypergammaglobulinaemia has been shown to correlate with the extent of Kupffer cell dysfunction rather than the degree of shunting. ${ }^{20}$ The observation that the greatest rise in circulating immunoglobulins usually occurs in autoimmune liver disease (chronic active hepatitis and primary biliary cirrhosis) might be explained by the coexistence of reduced suppressor cell activity, as this has been reported in both primary biliary cirrhosis $^{11}$ and chronic active hepatitis ${ }^{21}$ using immunoglobulin-producing systems but not in patients with alcoholic liver disease and hypergammaglobulinaemia. ${ }^{8}$ It has also been reported that in vivo antibody responses to tetanus toxoid are not increased in patients with cirrhotic hyperglobulinaemia ${ }^{22}{ }^{23}$ and this observation, together with the known correlations of the severity of the hyperglobulinaemia with the degree of Kupffer cell failure ${ }^{20}$ supports our impression that non-specific B-cell stimulation is the most important factor. It is possible that different results for different types of cirrhosis might be apparent in a study in which large numbers of patients would be studied.

We were unable to identify increased activity of a prostaglandin-producing suppressor cell system in cirrhotics using this system, although we have previously documented that this is present in proliferative assays in patients with cirrhosis. ${ }^{13}$ It is possible that differences might have been evident using other concentrations of indomethacin, but the level chosen in this study was that shown to reveal changes using a proliferative response assay. ${ }^{13}$ In Crohn's disease increased activity has been demonstrated both in the proliferative and in the immunoglobulin-producing assay, ${ }^{14}{ }^{24}$ and the lack of increased prostaglandin-producing suppressor cell activity on immunoglobulin production in cirrhotics may be relevant to the development of the hypergammaglobulinaemia. This system is monocyte mediated and in sarcoidosis, which is also associated with a polyclonal hyperglobulinaemia, B-cell activation has been shown to be suppressed by monocytes. ${ }^{25}$ It is possible that, in cirrhosis, continual non-specific B-cell stimulation results in a failure to respond to this regulatory system. Alternatively, the two may be more directly related, as we have shown that the inhibitory action of cirrhotic serum on proliferative responses is monocyte mediated ${ }^{13}$ and could result from stimulation by the same antigens that cause cirrhotic hyperglobulinaemia.

In conclusion, lymphocytes from cirrhotics produce significantly more spontaneous IgG than do controls. Exposure of normal cells to cirrhotic serum results in increased IgG production; this supports the theory that non-specific B-cell stimulation is important in the pathogenesis of the hypergammaglobulinaemia found in cirrhosis.

This work was supported by USPHS grants GC RR109, and NIH CA22435, the Gastrointestinal Vermont Education and Research Fund, and a grant from the American Cancer Society (Vermont Division). GH was in receipt of a Fulbright Travelling Fellowship.

\section{References}

1 Feizi T. Immunoglobulins in chronic liver disease. Gut 1968; 9: 193-8.

2 Triger DR, Alp MH, Wright R. Bacterial and dietary antibodies in liver disease. Lancet 1972; 1: 60-3.

3 Bjorneboe M, Prytz H, Orskov F. Antibodies to intestinal microbes in serum of patients with cirrhosis of the liver. Lancet 1972; 1: 58-60.

4 Young GP, Dudley FJ, Van der Weyden MB. Suppressive effect of alcoholic liver disease sera on lymphocyte transformation. Gut 1979; 20: 833-9.

5 Stobo JD. Cirrhosis and hypergammaglobulinaemia. Dig Dis Sci 1979; 24: 737-40.

6 Hodgson HJF, Wands JR, Isselbacher KJ. Alteration in suppressor cell activity in chronic active hepatitis. Proc Natl Acad Sci USA 1978; 75: 1549-53.

7 Kawanashi H. Tavassolie H, MacDermott RP, Sheagren JN. Impaired Concanavalin A-inducible suppressor $T$ cell activity in active alcoholic liver disease. Gastroenterology 1981; 80: 510-7.

8 Wands J, Dienstag JL, Weake JR, Koff R. In vitro studies of enhanced IgG synthesis in severe alcoholic liver disease. Clin Exp Immunol 1981; 44: 396-404.

9 Mutchnick MG, Lederman HM, Missirian A, Johnson 
AG. In vitro synthesis of IgG by peripheral blood lymphocytes in chronic liver disease. Clin Exp Immunol 1981; 43: 370-5.

10 Berger SR, Helms RA, Bull DM. Cirrhotic hyperglobulinaemia. Increased rates of immunoglobulin synthesis by circulating lymphoid cells. Dig Dis Sci 1979; 24: 741-5.

11 James SP, Elson CO, Jones EA, Strober W. Abnormal regulation of immunoglobulin synthesis in vitro in primary biliary cirrhosis. Gastroenterology 1980; 79: $242-54$.

12 Triger DR, Wright R. Hyperglobulinaemia in liver disease. Lancet 1973; 1: 1494-6.

13 Holdstock G, Chastenay B, Krawitt EL. Studies on lymphocyte hyporesponsiveness in cirrhosis: the role of increased monocyte suppressor cell activity. Gastroenterology 1982; 82: 206-12.

14 Holdstock G, Ershler WB, Krawitt EL. Defective lymphocyte production in inflammatory bowel disease. Clin Immunol Immunopathol 1982. (In press.)

15 Keightley RG, Cooper MD, Lawton AR. The T cell dependence of $B$ cell differentiation induced by pokeweed mitogen. J Immunol 1976; 117: 1538-44.

16 Engvall E, Perlmann P. Enzyme-linked immunosorbent assay (ELISA). Quantitative assay for immunoglobulin G. Immunochemistry 1971; 8: 871-4.

17 Thomas HC, Freni M, Sanchez-Tapias J, Devilliers D, Jain S, Sherlock S. Peripheral blood lymphocyte populations in chronic liver disease. Clin Immunol 1976; 26: 222-7.
18 Triger DR, Boyer TD, Levin J. Portal and systemic bacteraemia and endotoxaemia in liver disease. Gut 1978; 19: 935-9.

19 Pyrtz H, Holst Christiensen J, Korner B, Lieher H. Portal venous and systemic endotoxaemia in patients without liver disease and systemic endotoxaemia in patients with cirrhosis. Scand J Gastroenterol 1976; 11: $857-63$.

20 Pomier-Layrargues G, Huet PM, Richer G, Marleau D, Viallet A. Hyperglobulinaemia in alcoholic cirrhosis. Relationship with portal hypertension and intrahepatic portal-systemic shunting as assessed by Kupffer cell uptake. Dig Dis Sci 1980; 25: 489-93.

21 Kakumu S, Yata K, Kashio T. Immunoregulatory T-cell function in acute and chronic liver disease. Gastroenterology 1980; 79: 613-19.

22 Bjorneboe M, Jensen KB, Scheibel I, Chr Thomsen A, Bentzon MW. Tetanus antitoxin production and gamma globulin levels in patients with cirrhosis of the liver. Acta Med Scand 1970; 188: 541-6.

23 Cherrick GR, Pothier L, Dufour JJ, Sherlock S. Immunologic response to tetanus toxoid inoculation in patients with hepatic cirrhosis. $N$ Engl J Med 1959; 261: 340-2.

24 Holdstock G, Chastenay B, Krawitt EL. Increased suppressor cell activity in inflammatory bowel disease. Gut 1981; 22: 1025-30.

25 Katz P, Fauci AS. Inhibition of polyclonal B-cell activation by suppressor monocytes in patients with sarcoidosis. Clin Exp Immunol 1978; 32: 554-62. 